\title{
Fish assemblages in stream stretches occupied by cattail (Typhaceae, Angiospermae) stands in Southeast Brazil
}

\author{
Fabíola Carla da Rocha ${ }^{1}$, Lilian Casatti ${ }^{1}$, Fernando Rogério Carvalho² \\ and Alexandre Marco da Silva ${ }^{3}$
}

\begin{abstract}
Macrophytes are a major component of lentic and lotic aquatic ecosystems. As consequences of environmental degradation, species of cattail (genus Typha) may become dominant along streams. The purpose of this study was to investigate the structure and feeding of fish assemblages in stream stretches under influence of Typha sp., also addressing the influences of temporal variation on composition, abundance, biomass, diversity, species richness, and feeding of fish. Six streams (labelled S1-S6) in the upper rio Turvo basin, southeast Brazil, with dense stands of Typha sp. in the instream and riparian habitat, were studied in six campaigns during three central months in both of the dry and wet periods, by using a standardized collection effort. Thirty-seven fish species were registered, totaling 4,228 individuals and $3.9 \mathrm{~kg}$ of biomass. Abundance, biomass, diversity, and species richness was higher in the wet period, but only the temporal variation in the species richness revealed to be statistically significant. Cluster analyses with composition and abundance showed little temporal similarity, but indicated two groups of streams (S1-S2-S5 and S3-S4-S6), that were corroborated along the axis 1 of the ordination analysis. Resident species was represented by six species, most of them considered tolerant and generalists. Chironomidae aquatic larvae and detritus were the most important items in the fish diet. These results suggest that the fish populations are opportunistic in exploring stream stretches occupied by cattail.
\end{abstract}

Macrófitas são um importante componente de ecossistemas aquáticos lóticos e lênticos. Como consequências da degradação ambiental, espécies de taboas (gênero Typha) podem se tornar dominantes em riachos. O objetivo do presente estudo foi investigar a estrutura e alimentação de uma comunidade de peixes em trechos de riachos com influência de Typha sp., bem como a variação temporal na composição, abundância, biomassa, diversidade, riqueza de espécies e alimentação da ictiofauna. Seis riachos (nomeados S1-S6) na bacia do alto rio Turvo, sudeste do Brasil, com densos bancos de Typha sp. no habitat interno e ripário, foram estudados em seis campanhas durante os três meses centrais dos períodos seco e chuvoso, por meio de um esforço padronizado de coleta. Trinta e sete espécies foram registradas, totalizando 4.228 indivíduos e 3,9 kg de biomassa. Abundância, biomassa, diversidade e riqueza de espécies foram maiores no período chuvoso, mas somente as diferenças temporais na riqueza de espécies se mostraram estatisticamente significativas. As análises de agrupamentos com a composição e abundância mostraram baixa similaridade temporal, mas indicaram dois grupos de riachos (S1-S2-S5 e S3-S4S6), o que foi corroborado ao longo do eixo 1 da análise de ordenação. A fauna de peixes residente foi representada por seis espécies, a maioria tolerante e com hábitos generalistas. Larvas aquáticas de Chironomidae e detritos foram os itens mais importantes na dieta dos peixes. Os resultados obtidos sugerem que as populações de peixes exploram os trechos de riachos com Typha de forma oportunística.

Key words: Disturbance, Chironomidae larvae, Detritus, Macrophytes, Upper rio Paraná.

\footnotetext{
${ }^{1}$ UNESP - Universidade Estadual Paulista, Departamento de Zoologia e Botânica, IBILCE, Rua Cristóvão Colombo, 2265, Jardim Nazareth, 15054-000 São José do Rio Preto, SP, Brazil. rocha_fc@yahoo.com.br; lcasatti@ibilce.unesp.br ${ }^{2}$ UFRGS - Universidade Federal do Rio Grande do Sul, Departamento de Zoologia, Programa de Pós-Graduação em Biologia Animal, IB, Av. Bento Gonçalves, 9500, prédio 43435, 91501-970 Porto Alegre, RS, Brazil. frcarvalho2004@yahoo.com.br

${ }^{3}$ UNESP - Campus Experimental de Sorocaba, Av. Três de Março, 511, Alto da Boa Vista, 18087-180 Sorocaba, SP, Brazil. amsilva@sorocaba.unesp.br
} 


\section{Introduction}

Macrophytes play an important ecological role in aquatic ecosystems by promoting water oxygenation, protecting against erosive processes at the margins (Esteves \& Camargo, 1986), increasing physical heterogeneity and trapping sediments (Collier, 2002), acting as bioindicators (Demirezen \& Aksoy, 2006), and removing some chemical compounds from the water (Nilratnisakorn et al., 2007). Under particular types of disturbances, some species of macrophytes may become dominant (Foloni \& Pitelli, 2005).

Due to water pollution by organic wastes, dam constructions along water channels, clearing of catchments and riparian zones, aquatic weeds that so far passed unnoticed may form dense stands under eutrophic conditions (Patton \& Starnes, 1970). Increased available light due to clearing is considered to be the most important factor limiting macrophytes distribution and abundance (Canfield \& Hoyer, 1988). In Australia, for instance, extensive clearing of riparian vegetation in tropical cane-lands has created ideal light, water, and nutrients conditions for invasive macrophytes (Bunn et al., 1998). Cattail (genus Typha Linnaeus, 1753) is a weed that may become well established in disturbed riparian zones, being one of the most widely distributed genera of weeds in swamps and flooded areas worldwide. Moreover, some species of cattails are one of the few plants that may be found in areas degraded by industry or mining, often under conditions of altered water level, flow, and chemical compounds (Fyson, 2000).

Among the few studies that assessed the causes of cattail expansion in water bodies are those conducted in the northern region of the Everglades, USA (Newman et al., 1998). The following factors were considered to explain Typha spp. expansion in the region: frequent fires (Craighead, 1971), increased extension of flooding periods due to land use for agriculture (Grace, 1987, 1988), and increased nutrients input, particularly phosphorus, due to intensification of organic waste release (Keddy, 1990).

Though atypical, internal and riparian habitat of lowland streams being occupied by cattails seems to be currently very common in catchments used for sugarcane cultivation (pers. obs.). Among several adverse effects that cattail stands may cause to aquatic ecosystems are flow reduction with an in- crease of water infiltration into the soil and eroded material accumulation (Silva \& Martins, 2004), decrease in aquatic invertebrate productivity (Murkin et al., 1982), and reduction of open-water sloughs for foraging and nesting of wading birds (Crozier \& Gawlik, 2002). The purpose of this study was to investigate the structure and feeding of fish assemblages in stream stretches under influence of cattail (Typha sp.). The sampling design was proposed to assess whether composition, abundance, biomass, diversity, species richness, and feeding of fish exhibit temporal variation between dry and wet periods.

\section{Material and Methods}

Sampling design and study area. We selected six stream stretches - notably occupied by stands of Typha sp. in the internal and in the riparian habitat - of the upper rio Turvo basin (Table 1, Fig. 1), a tributary of rio Grande in the northeastern region of the São Paulo State. All streams were located in basins predominantly occupied by sugarcane cultivations and exhibited poor or very poor habitat conditions (according to Casatti et al., 2006). Sampling campaigns were conducted monthly during three central months of the dry period (July, August, and September, 2006) and wet (January, February, and March, 2007). Climatological variables, obtained from the Centre for Integrated Agrometeorological Information (http://www.ciiagro.sp.gov.br/ consulted on 29/Feb/2008), indicated that the peak of the dry season during the sampling period was in July 2006 (59 mm average monthly rainfall, $22^{\circ} \mathrm{C}$ average monthly temperature), whereas the peak of the rainy season was in December/January 2007 (148/146 mm average monthly rainfall, $25^{\circ} \mathrm{C}$ average monthly temperature).

Sampling of environmental descriptors and fish fauna. Length
of each stretch was determined based on the possibility of
collection equipments maneuverability since internal habi-
tat was covered by cattail at most sites. In each sampling
site, in the middle of each stream stretch, the pH, dissolved
oxygen, conductivity, temperature, and turbidity were mea-
sured with electronic equipment. Each stretch was divided
into sections of $5 \mathrm{~m}$ length (with the exception of S1 which

Table 1. Location and environmental descriptors of six stream stretches sampled in the upper rio Turvo basin, southeastern Brazil. * Strahler's convention (1:50.000 scale), ** visually categorized according to Cummnis' scale as cited by Hynes (2001), *** considering $30 \mathrm{~m}$ width of each margin at each studied segment.

\begin{tabular}{|c|c|c|c|c|c|c|}
\hline Descriptors & $\mathrm{S} 1$ & S2 & S3 & S4 & S5 & S6 \\
\hline \multirow{2}{*}{ Latitude (S) Longitude (W) } & $21^{\circ} 06^{\prime} 25.0^{\prime \prime}$ & $20^{\circ} 52^{\prime} 02.7^{\prime \prime}$ & $20^{\circ} 50^{\prime} 56.5^{\prime \prime}$ & $20^{\circ} 50^{\prime} 39.2^{\prime \prime}$ & $21^{\circ} 13^{\prime} 10.5^{\prime \prime}$ & $21^{\circ} 12^{\prime} 51.9^{\prime \prime}$ \\
\hline & $48^{\circ} 49^{\prime} 37.9^{\prime \prime}$ & $48^{\circ} 51^{\prime} 04.5^{\prime \prime}$ & $48^{\circ} 54^{\prime} 01.9 ”$ & $48^{\circ} 54^{\prime} 33.8^{\prime \prime}$ & 4853’39.0” & $48^{\circ} 53^{\prime} 48.2^{\prime \prime}$ \\
\hline Altitude at spring and at study location (m) & $590-560$ & $590-490$ & $520-490$ & $530-490$ & $580-550$ & $590-560$ \\
\hline Stream order* & 3 & 4 & 3 & 2 & 4 & 3 \\
\hline Main substrate** & sand & sand & sand & sand & sand & sand and gravel \\
\hline Woody debris & rare & absent & absent & absent & absent & rare \\
\hline Main mesohabitats & run & run and pool & run & run & run & run and pool \\
\hline$\%$ of Typha sp. it the riparian zone*** & 38.5 & 18.8 & 22.4 & 35.7 & 28.6 & 5.6 \\
\hline Length of sampling stretch (m) & 16 & 50 & 35 & 40 & 30 & 50 \\
\hline
\end{tabular}




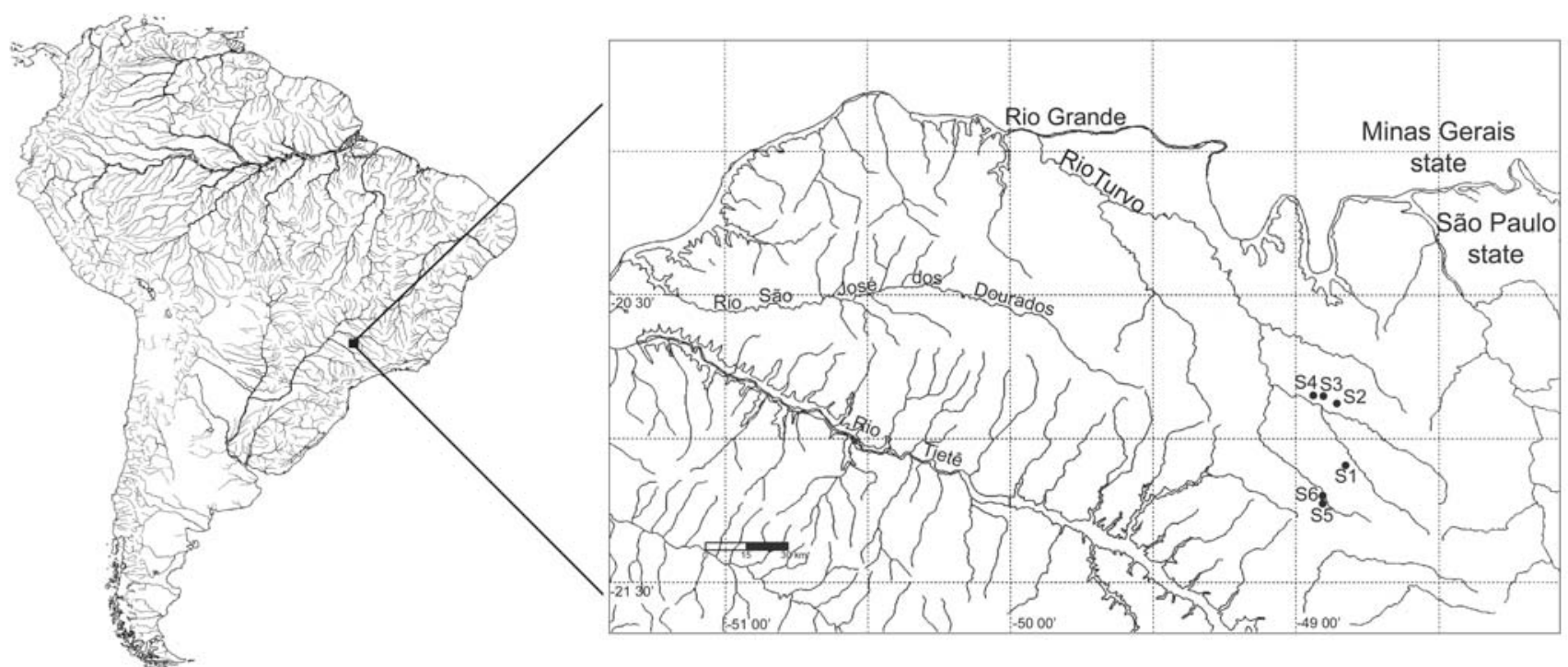

Fig. 1. Location of the sampling sites in the upper rio Paraná basin, southeast Brazil.

was subdivided every $2 \mathrm{~m}$ ), in which depth (in six equidistant points) and width were measured for subsequent calculation of the habitat volume. The current was measured three times with a mechanical flow meter operated for 30 seconds in the middle of each channel. Each stretch was isolated upstream and downstream with block nets $(5 \mathrm{~mm}$ mesh). Each of the following collection techniques was applied during 15 minutes: two circular sieves ( $3 \mathrm{~mm}$ mesh, 60 $\mathrm{cm}$ diameter), two dip nets ( $3 \mathrm{~mm}$ mesh, made with black fabric), and a hand seine ( $2 \mathrm{~m}$ width $\times 1.5 \mathrm{~m}$ height, $3 \mathrm{~mm}$ mesh). Fishes were fixed in $10 \%$ formalin solution and transferred to $70 \%$ EtOH solution after 48 to 72 hours. Voucher specimens are deposited in the fish collection at the Departamento de Zoologia e Botânica da Universidade Estadual Paulista (DZSJRP), São José do Rio Preto, São Paulo State, Brazil.

Analysis. Species diversity was given by Shannon-Wiener index (H') as described by Magurran (2004). The occurrence constancy $(\mathrm{C})$ was calculated by the formula $\mathrm{C}=(\mathrm{P} / \mathrm{Q}) \times 100$; where $\mathrm{P}$ is number of samples in which the species occurred and Q is the total number of samples (Dajoz, 1978). Following, each species was classified as resident (present in more than $50 \%$ of samples), accessory (present in 50 to $25 \%$ ), or accidental (present in $25 \%$ or less).

Gastric contents of at least five adult specimens of each species from each sample were examined under a stereomicroscope to achieve the most detailed identification. For species with an undifferentiated stomach, contents from the anterior third of digestive tubes were examined. The frequency of occurrence (Gelwick \& Matthews, 1996) and dominance (Hynes, 1950) of each food item were calculated. Composition percentage by number (Gelwick \& Matthews, 1996) was calculated for feeding items grouped into five categories (aquatic invertebrates, terrestrial invertebrates, algae/plants, fishes, detritus). The trophic group of each species was determined by the identification of the most representative feeding categories in each seasonal period, i.e., those more frequent and dominant according to Bennemann et al. (2006). To investigate temporal trophic niche breadth variation of common species in dry and wet periods, the occurrence of items grouped into five categories were used for the standardized Index of Levins calculations (Krebs, 1998).

To test if differences in the limnological and ecological descriptors were significant between the dry and wet periods, data normality was evaluated through Shapiro-Wilk test, with the help of BioEstat 3.0 software (Ayres et al., 2003). As some data did not agree with this assumption, non-parametric tests (Mann-Whitney, Kruskal-Wallis) were used with a significance level of $5 \%$.

Multivariate exploratory analyses were applied to identify patterns between the assemblages. First, the taxonomic and quantitative similarity of the fish fauna between streams was investigated. For taxonomic similarity, the Jaccard similarity coefficient was used in a presence/absence matrix; for quantitative similarity, the Bray-Curtis similarity coefficient was used in a squared root transformed density $/ \mathrm{m}^{2}$ matrix. In both analyses, the resulting dendrogram was produced by the method of average association (UPGMA, "arithmetic average clustering"), with the assistance of Biodiversity Pro software (McAleece et al., 1997).

The relationship between the physical and limnological descriptors (conductivity, dissolved oxygen, $\mathrm{pH}$, turbidity, and depth) and quantitative structure of the fish fauna was investigated by using the Canonical Correspondence Analysis (CCA), implemented in the CANOCO 4.5 computer program (Ter Braak \& Smilauer, 2002). Following recommendations by Ter Braak \& Smilauer (2002), species abundance matrix was transformed $[\ln (\mathrm{Ay}+\mathrm{B})]$ and, since the abiotic descriptors data were quantitative, relationships between 
species were emphasized; the biplot scaling option was also used to give a more quantitative interpretation of the ordination, especially recommended for cases of short gradients.

The trophic structure of the assemblages was investigated by the Non-Metric Multidimensional Scaling Analysis (NMDS) in the Primer v6 software (Clarke \& Gorley, 2006). To do this, a similarity matrix was generated with the percent composition values (transformed into $\log (\mathrm{x}+1)$ ) of species' diet of each site in dry and wet periods, using the Bray-Curtis similarity coefficient.

\section{Results}

Physical, limnological, and biological characterization. Temporal changes were detected for most of limnological descriptors (Table 2), but only conductivity showed significant variation between the dry and wet periods (Mann-Whitney, $\mathrm{p}=$ 0.003). A total of 37 fish species (Table 3) belonging to six orders and 13 families were registered, totaling 4,228 individuals and $3.9 \mathrm{~kg}$ of biomass. Despite temporal differences in ecological descriptors (Table 2), only the differences in the species richness showed to be statistically significant (Kruskal-Wallis, $\mathrm{p}=0.004$ ). It is noteworthy that in March 2007, at the S3 stream, several dead fishes were recorded and individuals of Astyanax altiparanae showed a projection of the lower lip.

The greatest similarity in taxonomic composition (70\%) between the dry and wet periods was registered for S6 (Fig. 2a), indicating little taxonomic variation between seasons in this stretch but higher temporal variations in the others. Quantitative structure of the fish fauna exhibited similar results, as two groups of streams were identified (S1, S2, S5 + S3, S4, S6) and only S5 and S6 exhibited temporal similarity higher than $50 \%$ (Fig. 2b). Of the 37 species collected, only six (Astyanax altiparanae, Corydoras aeneus, Gymnotus carapo,
Phalloceros harpagos, Poecilia reticulata, and Rhamdia quelen) were residents in the studied stretches and, even when analyzing each stream separately, representativeness of resident species was less than 58\% (Table 3).

Relationship between species and abiotic descriptors. The total, upstream, and downstream cattail percentages in the riparian zones were also tested as physical descriptors in a preliminary analysis. However, these three variables were automatically excluded because they did not add any information to the statistical model. Among the descriptors entered into the CCA model, turbidity ( $<<0.001$ ), conductivity $(p=0.017)$, depth $(p=0.229)$, dissolved oxygen $(p=0.611)$, and $\mathrm{pH}(\mathrm{p}=0.771)$ were those that best explain the generated ordination (Fig. 3). Ordination of sites produced by CCA along axis 1 showed same groups of streams revealed in the cluster analysis, differentiated by turbidity and depth, which were factors positively related to Corydoras aeneus, Imparfinis schubarti, Rhamdia quelen, and Hoplosternum littorale in streams S1, S2, and S5, whereas conductivity and dissolved oxygen were positively related to Tilapia rendalli and Parodon nasus in S3, S4, and S6.

Feeding analysis. Gastric contents of 2,001 specimens were examined, being 786 of the dry and 1,215 of the wet period. Aquatic invertebrates, but especially larvae of Chironomidae, were the main food items consumed by individuals of 14 species (Table 4). Detritus, which refers to a set of very fragmented organic items whose origin (animal or plant; autochthonous or allochthonous) could not be defined, was the predominant item consumed by four species. Invertebrates and detritus were frequent and dominant in the gastric contents of the other seven species that spatially and/ or temporally varied consumption of these items and, mainly due to this, some species were classified in different trophic categories in the dry and wet periods (Table 4). A stretch by stretch and an overall comparison with all stretches indi-

Table 2. Values of limnological (average) and ecological (absolute) descriptors of six stream stretches in the upper rio Turvo basin sampled during the dry period (D) and wet (W). All streams values are represented by mean and standard deviation.

\begin{tabular}{|c|c|c|c|c|c|c|c|c|c|c|c|c|c|c|}
\hline \multirow{2}{*}{ Descriptors } & \multicolumn{2}{|c|}{$\mathrm{S} 1$} & \multicolumn{2}{|c|}{$\mathrm{S} 2$} & \multicolumn{2}{|c|}{ S3 } & \multicolumn{2}{|c|}{ S4 } & \multicolumn{2}{|c|}{ S5 } & \multicolumn{2}{|c|}{ S6 } & \multicolumn{2}{|c|}{ All streams } \\
\hline & $\mathrm{D}$ & $\mathrm{W}$ & $\mathrm{D}$ & W & $\mathrm{D}$ & W & $\mathrm{D}$ & $\mathrm{W}$ & $\mathrm{D}$ & $\mathrm{W}$ & $\mathrm{D}$ & $\mathrm{W}$ & $\mathrm{D}$ & $\mathrm{W}$ \\
\hline \multicolumn{15}{|l|}{ Limnological: } \\
\hline $\mathrm{OD}\left(\mathrm{mg} \mathrm{l}^{-1}\right)$ & 3.2 & 2.5 & 2.7 & 2.1 & 1.5 & 2.7 & 2.6 & 3.6 & 3.2 & 3.0 & 3.9 & 4.6 & $2.9 \pm 0.8$ & $3.1 \pm 0.9$ \\
\hline Conductivity $\left(\mu \mathrm{S} \mathrm{cm}^{-1}\right)$ & 67 & 121 & 120 & 202 & 133 & 206 & 92 & 160 & 149 & 146 & 84 & 158 & $107.5 \pm 31.5$ & $165.5 \pm 32.9$ \\
\hline $\mathrm{pH}$ & 7.0 & 5.5 & 7.4 & 5.8 & 7.5 & 5.7 & 7.4 & 6.2 & 7.7 & 5.9 & 7.6 & 5.9 & $7.4 \pm 0.2$ & $5.8 \pm 0.2$ \\
\hline Turbidity (NTU) & 129 & 41 & 90 & 37 & 14 & 2 & 52 & 4 & 61 & 23 & 20 & 8 & $61.0 \pm 43.4$ & $19.2 \pm 17.1$ \\
\hline Temperature $\left({ }^{\circ} \mathrm{C}\right)$ & 16.5 & 23.3 & 19.6 & 26.4 & 19.9 & 24.3 & 18.2 & 24.0 & 18.1 & 24.2 & 18.9 & 24.1 & $18.5 \pm 1.2$ & $24.4 \pm 1.0$ \\
\hline Habitat volume $\left(\mathrm{m}^{3}\right)$ & 14.9 & 16.3 & 71.8 & 123.7 & 75.0 & 69.8 & 14.4 & 22.2 & 39.1 & 91.7 & 69.3 & 104.8 & $47.4 \pm 28.5$ & $71.4 \pm 44.1$ \\
\hline Current $\left(\mathrm{m} \mathrm{s}^{-1}\right)$ & 0.4 & 0.4 & 0.2 & 0.3 & $<0.1$ & 0.4 & 0.4 & 0.5 & 0.4 & 0.44 & $<0.1$ & $<0.1$ & $0.3 \pm 0.2$ & $0.4 \pm 0.1$ \\
\hline Width (m) & 1.5 & 1.7 & 2.9 & 3.3 & 4.2 & 2.9 & 1.5 & 1.7 & 2.7 & 2.9 & 2.6 & 2.7 & $2.6 \pm 1.0$ & $2.5 \pm 0.7$ \\
\hline Depth (m) & 0.8 & 0.9 & 0.9 & 1.2 & 0.9 & 1.0 & 0.3 & 0.5 & 1.0 & 2.3 & 0.9 & 1.1 & $0.8 \pm 0.3$ & $1.2 \pm 0.6$ \\
\hline \multicolumn{15}{|l|}{ Ecological: } \\
\hline Abundance & 47 & 111 & 104 & 222 & 245 & 1071 & 415 & 259 & 192 & 438 & 475 & 649 & $246 \pm 169$ & $458 \pm 354$ \\
\hline Biomass (g) & 83 & 53 & 158 & 152 & 558 & 589 & 741 & 609 & 137 & 310 & 283 & 205 & $326.7 \pm 264.9$ & $319.7 \pm 231.8$ \\
\hline Diversity (H’) & 1.79 & 1.81 & 1.34 & 1.96 & 1.93 & 1.99 & 1.04 & 1.98 & 2.29 & 1.94 & 1.62 & 2.33 & $1.67 \pm 0.44$ & $2.0 \pm 0.17$ \\
\hline Species richness & 9 & 9 & 10 & 16 & 15 & 21 & 9 & 21 & 16 & 17 & 15 & 18 & $12 \pm 3$ & $17 \pm 4$ \\
\hline Trophic niche breadth (Ba) & 0.56 & 0.39 & 0.33 & 0.30 & 0.44 & 0.39 & 0.64 & 0.53 & 0.44 & 0.43 & 0.65 & 0.42 & $0.5 \pm 0.1$ & $0.4 \pm 0.1$ \\
\hline
\end{tabular}


Table 3. Species, species codes, abundance and their occurrence (RE, resident; AE, accessory; AI, accidental) in the six stream stretches (S1-S6) studied in the upper rio Turvo basin.

\begin{tabular}{|c|c|c|c|c|c|c|c|}
\hline Species & Codes & S1 & S2 & S3 & S4 & S5 & S6 \\
\hline Aspidoras fuscoguttatus & Aspfus & $3(\mathrm{AI})$ & $1(\mathrm{AI})$ & - & 9 (RE) & - & - \\
\hline Astyanax altiparanae & Astalt & $28(\mathrm{AE})$ & 82 (RE) & 235 (RE) & $24(\mathrm{RE})$ & $67(\mathrm{RE})$ & 37 (RE) \\
\hline Astyanax bockmanni & Astboc & - & - & - & - & - & $1(\mathrm{AI})$ \\
\hline Astyanax fasciatus & Astfas & $12(\mathrm{AE})$ & 21 (AE) & - & $8(\mathrm{AE})$ & 121 (RE) & $64(\mathrm{AE})$ \\
\hline Astyanax paranae & Astpar & 20 (RE) & - & - & $2(\mathrm{AE})$ & $17(\mathrm{AE})$ & - \\
\hline Callichthys callichthys & Calcal & $3(\mathrm{AE})$ & $2(\mathrm{AE})$ & - & - & - & - \\
\hline Characidium zebra & Chazeb & - & - & - & 2 (AI) & - & - \\
\hline 'Cheirodon' stenodon & Cheste & - & - & - & - & $10(\mathrm{AE})$ & - \\
\hline Cichlasoma paranaense & Cicpar & - & - & $1(\mathrm{AI})$ & - & - & - \\
\hline oras aeneus & Coraen & $22(\mathrm{AE})$ & 25 (RE) & 58 (RE) & $3(\mathrm{AE})$ & 25 (RE) & 26 (RE) \\
\hline ichla britskii & Crebri & - & - & $1(\mathrm{AI})$ & - & - & - \\
\hline arax modestus & Cypmod & - & $1(\mathrm{AI})$ & E) & - & $1(\mathrm{AI})$ & $10(\mathrm{AI})$ \\
\hline erythrinus & yery & - & $1(\mathrm{AI})$ & E) & $2(\mathrm{AE})$ & $5(\mathrm{AE})$ & 17 (RE) \\
\hline Geophagus brasiliensis & Geobra & - & $2(\mathrm{AI})$ & $5(\mathrm{RE})$ & $9(\mathrm{AE})$ & $4(\mathrm{AE})$ & 14 (RE) \\
\hline carapo & Gymcar & $4(\mathrm{AE})$ & $3(\mathrm{AE})$ & 10 (RE) & $16(\mathrm{RE})$ & $25(\mathrm{RE})$ & $24(\mathrm{RE})$ \\
\hline Hisonotus francirochai & Hisfra & - & - & $1(\mathrm{AI})$ & 26 (AE) & $2(\mathrm{AI})$ & - \\
\hline alabaricus & Hopmal & - & - & $26(\mathrm{AE})$ & - & 1 (AI) & $9(\mathrm{AE})$ \\
\hline num littorale & oplit & - & $6(\mathrm{AI})$ & $2(\mathrm{AE})$ & - & $2(\mathrm{AE})$ & - \\
\hline nisitsi & ni & - & $5(\mathrm{AI})$ & 25 & $2(\mathrm{AI})$ & 18 (AE) & 261 (RE) \\
\hline nus ancistroides & Hypanc & 38 (RE) & $13(\mathrm{AE})$ & $10(\mathrm{AE})$ & $10(\mathrm{AE})$ & 156 (RE) & 15 (AE) \\
\hline finis schubarti & Impsch & $10(\mathrm{AE})$ & - & $2(\mathrm{AE})$ & 17 (RE) & 46 (AE) & - \\
\hline$a$ aff. dorsigera & aedor & - & 1 (AI) & - & - & - & - \\
\hline usia sanctaefilomenae & Moesan & - & - & - & - & - & 7 (AE) \\
\hline ilbe sp. n. & Odosp & - & - & $4(\mathrm{AI})$ & - & - & - \\
\hline s pintoi & Olipin & - & - & 13 (RE) & $8(\mathrm{AF}$ & - & 120 (RE) \\
\hline Parodor & Parnas & - & - & - & $10(\mathrm{AE})$ & - & - \\
\hline os harpagos & Phacau & - & - & 44 (RE) & 373 (RE) & $4(\mathrm{AI})$ & 330 (RE) \\
\hline Pimelodella avanhandavae & Pimava & $3(\mathrm{AE})$ & 30 (RE) & $1(\mathrm{AI})$ & $3(\mathrm{AI})$ & $6(\mathrm{AE})$ & - \\
\hline Poecilia reticulata & Poeret & $5(\mathrm{AE})$ & $144(\mathrm{RE})$ & 444 (RE) & $141(\mathrm{RE})$ & $106(\mathrm{RE})$ & $116(\mathrm{RE})$ \\
\hline Pterygoplichthys ambrosettii & Pteamb & - & $1(\mathrm{AI})$ & - & - & - & - \\
\hline Rhamdia quelen & Rhaque & $10(\mathrm{AE})$ & $16(\mathrm{AE})$ & $51(\mathrm{RE})$ & $6(\mathrm{AE})$ & 6 (RE) & 7 (RE) \\
\hline Salminus hilarii & Salhil & - & - & - & $1(\mathrm{AI})$ & - & - \\
\hline Serrapinnus heterodon & Serhet & - & - & - & - & 2 (AI) & - \\
\hline Serrapinnus notomelas & & - & 1 (AI) & 180 (RE) & - & $1(\mathrm{AI})$ & 57 (RE) \\
\hline Steindachnerina insculpta & & - & - & 8 (AI) & 2 (AI) & $5(\mathrm{AE})$ & $3(\mathrm{AE})$ \\
\hline Synbranchus marmoratus & Synmar & - & - & - & - & - & $6(\mathrm{AE})$ \\
\hline Tilapia rendalli & Tilren & - & $1(\mathrm{AI})$ & $15(\mathrm{AE})$ & - & - & - \\
\hline Accessory + accidental pe & entage & 83 & 78 & 48 & 71 & 70 & 42 \\
\hline
\end{tabular}

cated that trophic niche breadth was lower in the wet season (Table 2). Overall, despite the importance of invertebrate and detritus in feeding for most fishes, diet composition demonstrated temporal variation as indicated by the ordination of two gradients of stream samples in the Figure 4a. Some specific food items were determinant for the resulting ordination, such as aquatic larvae of Ceratopogonidae that were more representative in the dry period (Fig. 4b), and Coleoptera larvae (Fig. 4c) and Collembola in the wet period (Fig. 4d).

\section{Discussion}

Despite limnological descriptors having exhibited temporal differences, only conductivity proved to be significantly higher in the wet period. At this time of year land-water interaction is greater (larger stream area and volume), promoting greater leaching, ions transportation, and submerged organic matter decomposition; also, the wet period (January to March) is the hottest time of the year, with higher water temperatures, which is one of the factors associated to increase of conductivity (Esteves, 1998).

When compared to other studies carried out in stretches without cattail influences (Casatti et al., 2006; Ferreira \& Casatti, 2006), dissolved oxygen values were lower. Study sites are influenced by a range of anthropogenic impacts, making it difficult to identify factors associated to oxygen depletion, but considering the relatively highest values in the stretch S6, where Typha proportion was the lowest, there are some local factors that presumably contribute to oxygen depletion. Among them, there are the detritus accumulation among cattail roots that, consequently, demands oxygen during its decomposition (Esteves, 1998), and the flow reduction due to channel occupation by cattail that decreases the mechanical oxygenation of water. In reference to the proliferation of littoral grasses, Pusey \& Arthington (2003) mentioned the high rates of plant respiration and reduced recharge as additional factors explaining depressed oxygen values. In fact, the registration of Astyanax altiparanae individuals with a projection of the lower lip exemplifies an extreme case of hypoxia, because this projection is an adjustment that arises in 

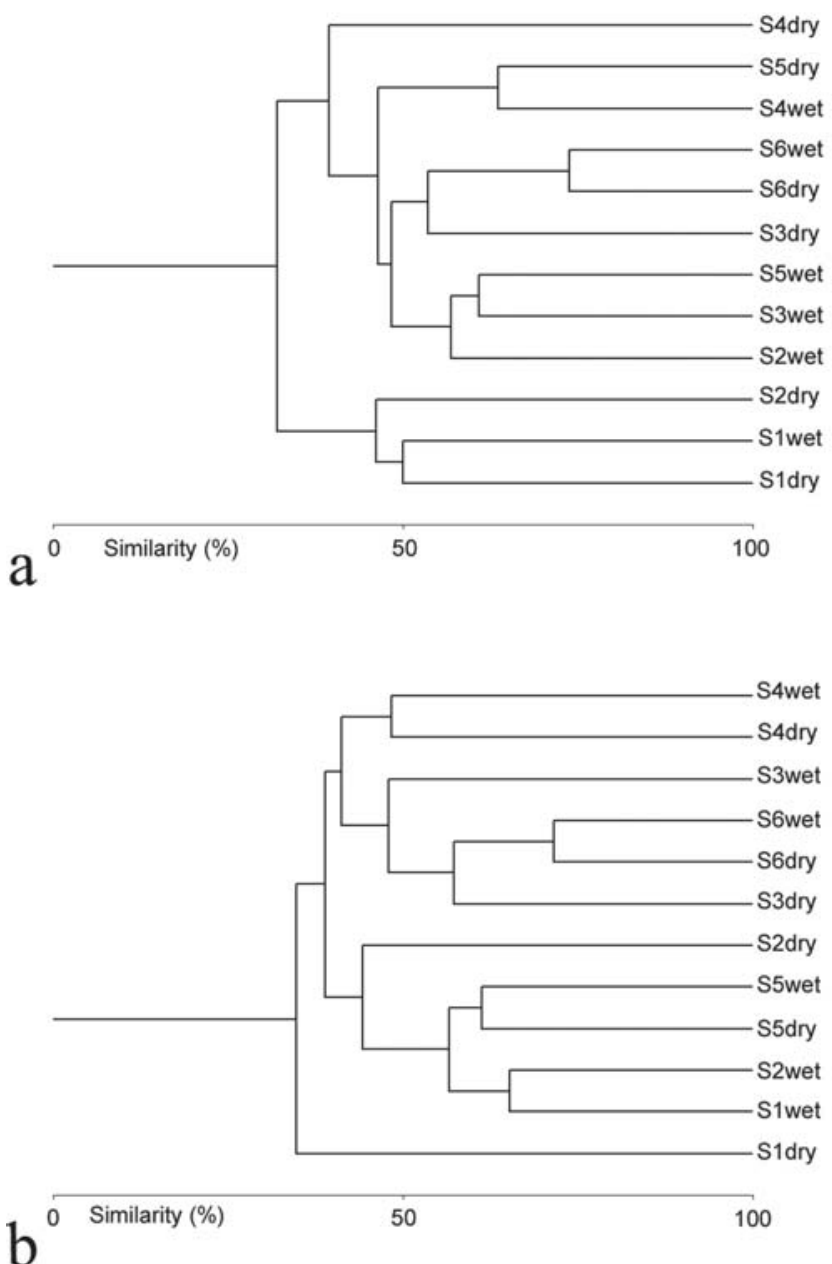

Fig. 2. (a) Dendrogram showing species composition similarity among six stream stretches sampled in the dry and wet periods (Jaccard coefficient and UPGMA). (b) Dendrogram showing quantitative similarity among six sampled streams in the dry and wet periods (Bray-Curtis coefficient and UPGMA).

a few hours under hypoxic conditions, allowing fish to capture more oxygen from water surface (Agostinho et al., 2007). An additional strategy for fish deal with low oxygenated conditions is the use of water surface as corridors to travel until oxygenated pockets are located, which was suggested from studies done in inhospitable aquatic plant stands (Miranda et al., 2000).

The largest abundance of fish was recorded in the wet period and this fact is already a well known pattern for Neotropical fish fauna, associated to the intensification of the reproductive period and recruitment of individuals from adjacent areas (Lowe-McConnell, 1987). As no temporal differences in biomass were detected and the proportion of young individuals was higher in the wet period (pers. obs.), it is likely that reproduction intensification (either on-site or in adjacent areas) is the main factor responsible for higher abun-

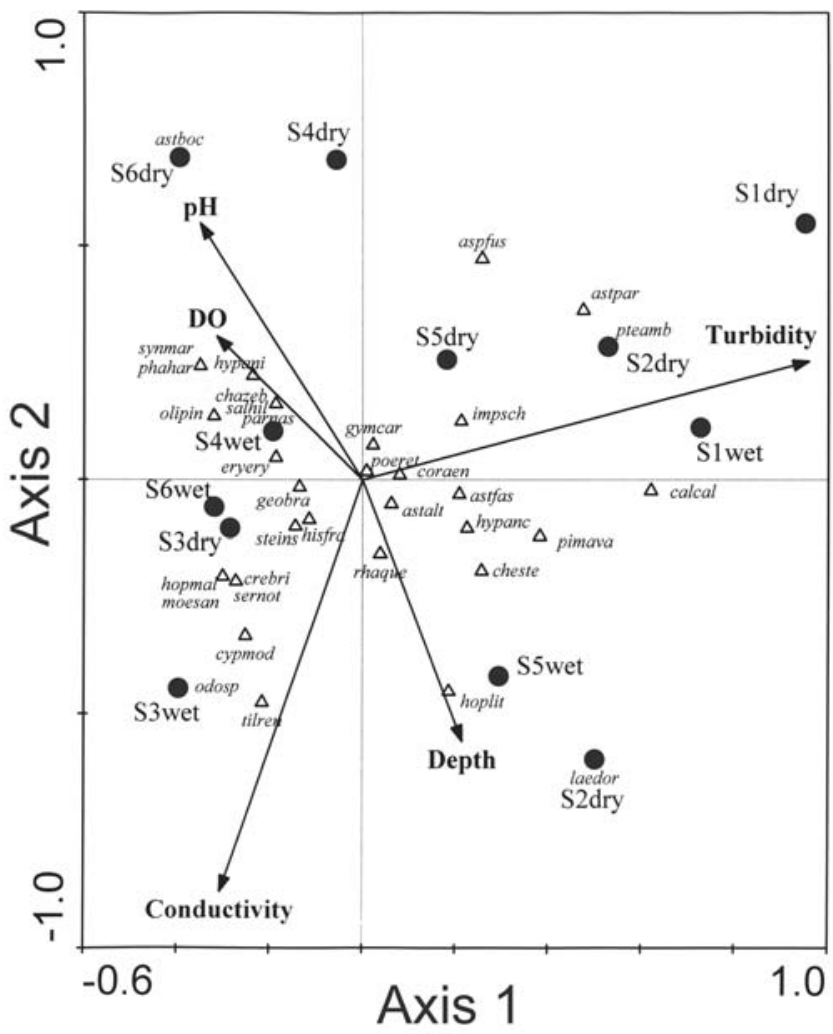

Fig. 3. Representation the two first axis of the Canonical Correspondence Analysis, showing the sampled stretches (labelled S1-S6) in the dry and wet periods (circles), species (triangles), and environmental descriptors (arrows). The eigenvalue of axis 1 and axis 2 are 0.26 and 0.16 , respectively, displaying $38 \%$ of the total inertia (= weighted variance) in the abundances and $68.8 \%$ of the variance in the weighted averages and class total of species with respect to the environmental variables. Monte Carlo significance test (4.999 permutations) under the full model option indicate that canonical axes are marginally significant ("F-ratio" $=1.509$, P-value $=0.09$ ). . To species codes see Table 3 .

dances in the wet period.

The species richness (37 species) recorded in this study is comparable to previous studies in the region, conducted in streams without cattail influence and using two passes of electric fishing in $75 \mathrm{~m}$ sections, which supposedly is a more efficient sampling effort. For example, in the study of Ferreira \& Casatti (2006), in four sections of a stream, 27 species were documented in six campaigns; Casatti et al. (2006) recorded 50 species in 35 sections of streams sampled once. Despite presenting species richness comparable to stretches free of Typha influences, the resident fauna is simplified, consisting of six species (Astyanax altiparanae, Corydoras aeneus, Gymnotus carapo, Phalloceros harpagos, Poecilia reticulata, and Rhamdia quelen), most of them tolerant and generalists (Casatti et al., 2009).

The predominant feeding item both in the dry period and 
Table 4. Trophic categories of each species examined of six stream stretches (S1-S6) in the dry (D) and wet (W) periods.

\begin{tabular}{|c|c|}
\hline Categories and species & Streams and periods \\
\hline \multicolumn{2}{|l|}{ Invertivorous (14 species): } \\
\hline Aspidoras fuscoguttatus & S4 D \\
\hline Geophagus brasiliensis & S4 W, S6 W \\
\hline Hoplias malabaricus & S3 W, S6 W \\
\hline Hoplosternum littorale & S2 W \\
\hline Imparfinis schubarti & S1 W, S4 D/W, S5 W \\
\hline Moenkhausia sanctaefilomenae & S6 W \\
\hline Odontostilbe sp. n. & S3 W \\
\hline Oligosarcus pintoi & S3 D, S4 W, S6 D/W \\
\hline Parodon nasus & S4 D \\
\hline Pimelodella avanhandavae & S2 D/W, S5 W \\
\hline Poecilia reticulata & S1 W, S2 D/W, S3 D/W, S4 D, S6 D/W \\
\hline Rhamdia quelen & S1 W, S2 W, S3 D/W, S4 W, S6 W \\
\hline Serrapinnus notomelas & S3 D/W, S6 W \\
\hline Tilapia rendalli & S3 W \\
\hline \multicolumn{2}{|l|}{ Detritivorous (4 species): } \\
\hline Cyphocharax modestus & S3 W, S6 W \\
\hline Hisonotus francirochai & S4 D \\
\hline Hypostomus ancistroides & S1 D/W, S2 W, S3 W, S4 W, S5 D/ W \\
\hline Steindachnerina insculpta & S3 W \\
\hline \multicolumn{2}{|l|}{ Herbivorous (1 species): } \\
\hline Astyanax paranae & S1 D \\
\hline \multicolumn{2}{|l|}{ More than one trophic group ( 7 species): } \\
\hline Astyanax altiparanae & $\begin{array}{c}\text { Herbivorous: S3 D } \\
\text { Invertivorous: S1 W, S2 D/W, S3 W, S4 D/W, S5 D/W, S6 D/W }\end{array}$ \\
\hline Astyanax fasciatus & $\begin{array}{c}\text { Herbivorous: S5 D } \\
\text { Invertivorous: S1 W, S2 D/W, S3 W, S4 D/W, S5 D/W, S6 D/W }\end{array}$ \\
\hline Corydoras aeneus & $\begin{array}{c}\text { Herbivorous: S6 D } \\
\text { Invertivorous: S1 W, S2 D/W, S3 D/W, S6 W }\end{array}$ \\
\hline Erythrinus erythrinus & $\begin{array}{c}\text { Invertivorous: S3 W, S6 D } \\
\text { Omnivorous: S3 D } \\
\text { Herbivorous: S5 D }\end{array}$ \\
\hline Gymnotus carapo & $\begin{array}{c}\text { Invertivorous: S3 W, S4 D, S5 W, S6 D/W } \\
\text { Detritivorous: S4 W }\end{array}$ \\
\hline Hyphessobrycon anisitsi & $\begin{array}{l}\text { Herbivorous: S3 D/W, S5 D, S6 D/W } \\
\text { Invertivorous: S2 D }\end{array}$ \\
\hline Phalloceros harpagos & $\begin{array}{l}\text { Detritivorous: S4 D, S5 D, S6 D/W } \\
\text { Invertivorous: S3 D/W, S4 W, S5 W }\end{array}$ \\
\hline
\end{tabular}

wet were aquatic larvae of Chironomidae, an abundant food resource in streams (Uieda \& Motta, 2007). Indeed, detritus, despite having a questionable nutritional relevance (Bowen, 1984), was also an expressive item in terms of frequency and dominance. It is likely that detritus may be retained among cattail's stems and roots, available throughout the water column, since it was recorded in the diet of species that explore different microhabitats, such as water surface (Phalloceros harpagos, Casatti, 2002; Poecilia reticulata, Ferreira \& Casatti, 2006), marginal banks of vegetation (Gymnotus carapo, Ferreira \& Casatti, 2006), and stream bottom (Cyphocharax modestus, Novakowski et al., 2007; Hypostomus ancistroides, Casatti, 2002).

Seven species were classified in more than one trophic category, reflecting the trophic plasticity of stream ichthyofauna that, in the absence of food resources, may use those with greater availability at the time (Esteves \& Aranha, 1999; Hahn et al., 2004). Overall, fishes were more specialists in the wet period, in opposition to the some studies in Neotropical streams that have reported a more generalist diet in the rainy season when resources are more abundant (Prejs \&
Prejs, 1987; Deus \& Petrere Jr., 2003). If on one hand, greater diversity and abundance of resources may lead to opportunistic use, resulting in a more generalist food spectrum, on the other hand, specialization trends can be explained by the choice of nutritionally more important items in wet season (Ceneviva-Bastos \& Casatti, 2007), available to fish due to the increase in general productivity and/or the mechanical action of runoffs (Angermeier \& Karr, 1983). The record of terrestrial Collembola and Coleoptera larvae in the gastric contents from the wet period season may reflect the action of runoffs, representing a common event which carries terrestrial insects into the instream habitat (see Pinto \& Uieda, 2007), and in this sense, dragged invertebrates may be retained among cattail's stems and roots. During the dry season, in contrast, the largest niche breadth indicates a more diverse feeding, which is characteristic of abundant species, adapted to unstable environments (Levins, 1968).

The low temporal similarity in composition and structure (except for S6) complements the frequency of occurrence results and reinforces the fact that few fish species are resident in the study stretches. CCA analysis revealed 

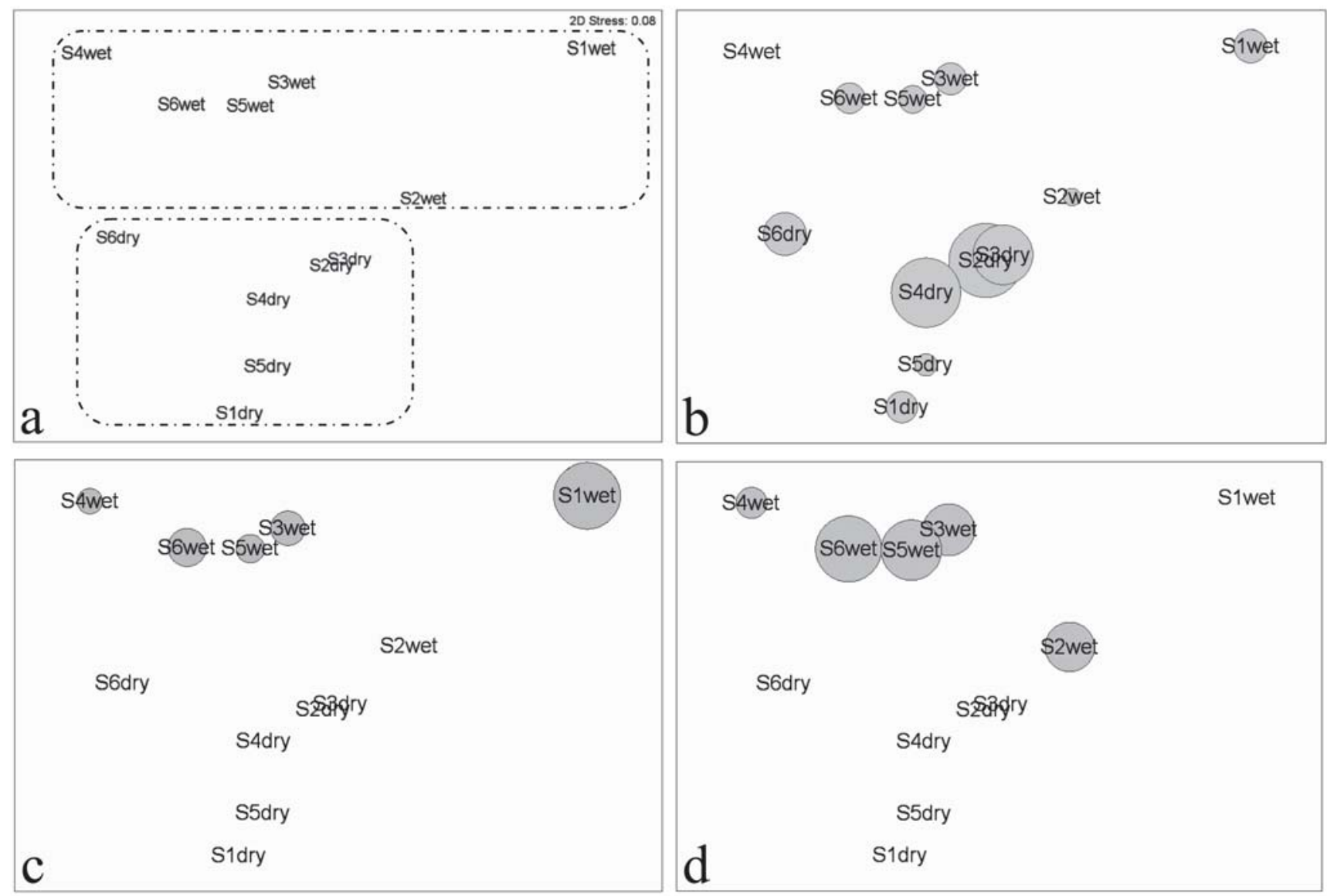

Fig. 4. (a) Ordination resulting from Nonmetric Multidimensional Scaling Analysis (NMDS) with percent composition by number of feeding items from fishes of six stream stretches (S1-S6) in the dry and wet periods. (b, c, d) Contribution (the larger the circle, the greater the percent composition by number) of Ceratopogonidae larvae (b), Coleoptera larvae (c), and Collembola (d) to the fishes' diet. A stress of 0.08 corresponds to a good ordination with no real prospect of a misleading interpretation (Clarke \& Warwick, 2001).

interesting species-habitat relationships. For example, species associated with turbidity and depth - Rhamdia quelen and Hoplosternum littorale - are invertivore predators which normally present better performances in deeper and more turbid microhabitats than visually orientated species (pers. obs.). Also, Hoplosternum littorale is a facultative air breather, that is known to be an important strategy for surviving in hypoxia (Brauner et al., 1995) and, hence, they are able to survive in hypoxic conditions as observed in S1, S2, and S5, sites that were densely occupied by cattails. Characidium zebra and Parodon nasus are typical riffle species (see Casatti \& Castro, 1998), with close association to environments with higher concentrations of dissolved oxygen, as observed in S6, the site with lower density of cattails.

To synthesize, the high incidence of accessory/accidental species, representativeness of tolerant and trophic generalist species, importance of aquatic larvae of Chironomidae and detritus in the fish diet, in addition to the low temporal similarity in the composition and structure of the fish fauna, are facts that suggest that the fish populations are opportunistic in exploring stream stretches occupied by cattail.

\section{Acknowledgements}

We thank IBAMA for the collecting license (109/2006 DIPAP/IBAMA, 28/Dec/2006), Katharina E. Esteves and Denise C. Rossa-Feres for suggestions, David R. Mercer for language revision, Peterson R. Demite for helping with invertebrates identification, anonymous reviewers for helpful comments that improved the manuscript, Fundação de Amparo à Pesquisa do Estado de São Paulo (FAPESP/Biota Program, grants 01/133407, 05/03291-0) and Conselho Nacional de Desenvolvimento Científico e Tecnológico (CNPq, grant 555096/2006-8) for financial support. LC receives grant from CNPq (303647/2007-8), AMS received grant from FAPESP (proc 04/15796-6), FRC is a doctoral fellowship from CNPq (141028/2007-6). 


\section{Literature Cited}

Agostinho, A. A., L. C. Gomes \& F. M. Pelicice. 2007. Ecologia e manejo de recursos pesqueiros em reservatórios do Brasil. Maringá, EDUEM, 501p.

Angermeier, P. L. \& J. R. Karr. 1983. Fish communities along environmental gradients in a system of tropical streams. Environmental Biology of Fishes, 9(2): 117-135.

Ayres, M., M. Jr. Ayres, D. L. Ayres \& A. S. dos Santos. 2003. BioEstat 3.0: aplicações estatísticas nas áreas das ciências biológicas e médicas. Belém, Sociedade Civil Mamirauá, 291p.

Bennemann, S. T., L. Casatti \& D. C. Oliveira. 2006. Alimentação de peixes: proposta para análise de itens registrados em conteúdos gástricos. Biota Neotropica, 6(2): 1-8.

Bowen, S. H. 1984. Detritivory in neotropical fish communities. Pp. 59-66. In: Zaret, T. M. (Ed.). Evolutionary ecology of neotropical freshwater fishes. The Hague, Dr. W. Junk Publisher, 173p.

Brauner, C. J., C. L. Ballantyne, D. J. Randall \& A. L. Val. 1995. Air-breathing in the armored catfish (Hoplosternum littorale) as an adaptation to hypoxic, acidic, and hydrogen-sulfide rich waters. Canadian Journal of Zoology, 73(4): 739-744.

Bunn, S. E., P. M. Davies, D. M. Kellaway \& I. P. Prosser. 1998. Influence of invasive macrophytes on channel morphology and hydrology in an open tropical lowland stream, and potential control by riparian shading. Freshwater Biology, 39(1): 171178.

Canfield, D. E. \& M. V. Jr. Hoyer. 1988. Influence of nutrient enrichment and light availability on the abundance of aquatic macrophytes in Florida streams. Canadian Journal of Fisheries and Aquatic Sciences, 45(8): 1467-1472.

Casatti, L. 2002. Alimentação dos peixes em um riacho do Parque Estadual Morro do Diabo, bacia do Alto Paraná, sudeste do Brasil. Biota Neotropica, 2(2): 1-14.

Casatti, L. \& R. M. C. Castro. 1998. A fish community of the São Francisco River headwaters riffles, southeastern Brazil. Ichthyological Exploration of Freshwaters, 9(3): 229-242.

Casatti, L., C. P. Ferreira \& F. Langeani. 2009. A fish-based biotic integrity index for assessment of lowland streams in southeastern Brazil. Hydrobiologia, 623:173-189.

Casatti, L., F. Langeani, A. M. Silva \& R. M. C. Castro. 2006. Stream fish, water and habitat quality in a pasture dominated basin, southeastern Brazil. Brazilian Journal of Biology, 66(2B): 681-696.

Ceneviva-Bastos, M. \& L. Casatti. 2007. Oportunismo alimentar de Knodus moenkhausii (Teleostei, Characidae): uma espécie abundante em riachos do noroeste do Estado de São Paulo, Brasil. Iheringia, Série Zoologia, 97(1): 7-15.

Clarke, K. R. \& R. N. Gorley. 2006. Primer v6: user manual/tutorial. Plymouth, Plymouth Marine Laboratory, 190p.

Clarke, K. R. \& R. M. Warwick. 2001. Change in marine communities: an approach to statistical analysis and interpretation. Plymouth, Plymouth Marine Laboratory, 172p.

Collier, K. J. 2002. Effects of flow regulation and sediment flushing on instream habitat and benthic macroinvertebrates in a New Zealand river influenced by a volcanic eruption. River Research and Application, 18(3): 213-226.

Craighead, F. C. 1971. The trees of South Florida: the natural environments and their succession. Coral Gables, University of Miami Press, 212p.

Crozier, G. E. \& D. E. Gawlik. 2002. Avian response to nutrient enrichment in an oligotrophic wetland, the Florida Everglades.
The Condor, 104(3): 631-642.

Dajoz, R. 1978. Ecologia geral. Petrópolis, Editora Vozes, 472p.

Demirezen, D. \& A. Aksoy. 2006. Common hydrophytes as bioindicators of iron and manganese pollutions. Ecological Indicators, 6: 388-393.

Deus, C. P. \& M. Petrere-Jr. 2003. Seasonal diet shifts of seven fish species in an Atlantic rainforest stream in Southeastern Brazil. Brazilian Journal of Biology, 63(4): 579-588.

Esteves, F. A. 1998. Fundamentos de limnologia. Rio de Janeiro, Interciência, 602p.

Esteves, F. A. \& A. F. M. Camargo. 1986. Sobre o papel das macrófitas aquáticas na estocagem e ciclagem de nutrientes. Acta Limnologica Brasiliensia, 1: 273-298.

Esteves, K. E. \& J. M. R. Aranha. 1999. Pp: 157-182. Ecologia trófica de peixes de riachos. In: Caramaschi, E. P. R., R. Mazzoni \& P. R. Peres-Neto (Eds.). Ecologia de Peixes de Riachos. Vol. VI. Oecologia Brasiliensis. Rio de Janeiro, Programa de PósGraduação em Ecologia UFRJ, 260p.

Ferreira, C. P. \& L. Casatti. 2006. Influência da estrutura do hábitat sobre a ictiofauna de um riacho em uma micro-bacia de pastagem, São Paulo, Brasil. Revista Brasileira de Zoologia, 23(3): 642-651.

Foloni, L. L. \& R. A. Pitelli. 2005. Avaliação da sensibilidade de diversas espécies de plantas de plantas daninhas aquáticas ao carfentrazone-ethyl, em ambiente controlado. Planta Daninha, 23(2): 329-334.

Fyson, A. 2000. Angiosperms in acidic waters at pH 3 and below. Hydrobiologia, 433: 129-135.

Gelwick, F. P. \& W. J. Matthews. 1996. Trophic relations of stream fishes. Pp. 475-492. In: Lamberti, G. \& R. Hauer (Eds.). Methods in stream ecology. New York, Academic Press, 1052p.

Grace, J. B. 1987. The impact of preemption on the zonation of two Typha species along lakeshores. Ecological Monographs, 57: 283-303.

Grace, J. B. 1988. The effects of nutrient additions on mixtures of Typha latifolia L. and Typha domingensis Pers. along a water depth gradient. Aquatic Botany, 31: 83-92.

Hahn, N. S., R. Fugi \& I. F. Andrian. 2004. Trophic ecology of the fish assemblages. Pp. 247-269. In: Thomaz, S. M., A. A. Agostinho \& N. S. Hahn (Eds.). The Upper Paraná River and its floodplain: physical aspects, ecology and conservation. Leiden, Backhuys Publishers, 393p.

Hynes, H. B. N. 1950. The food of fresh-water sticklebacks (Gasterosteus aculeatus and Pygosteus pungitius), with a review of methods used in studies of the food of fishes. The Journal of Animal Ecology, 19(1): 36-58.

Hynes, H. B. N. 2001. The ecology of running waters. Reprint of the first edition, New Jersey, The Blackburn Press, 555p.

Keddy, P. A. 1990. Competitive hierarchies and centrifugal organization in plant communities. Pp. 265-290. In: Grace, J. B. \& D. Tilman (Eds.). Perspectives on Plant Competition. New York, Academic Press, 484p.

Krebs, C. J. 1998. Ecological methodology. California, Addison Wesley Longman, 620p.

Levins, R. 1968. Evolution in changing environments, some theoretical explorations. Monographs in Population Biology, 2: $1-120$.

Lowe-McConnell, R. H. 1987. Ecological studies in tropical fish communities. Cambridge, Cambridge University Press, 382p.

Magurran, A. E. 2004. Measuring Biological Diversity. United Kingdom, Blackwell Publishing, 256p.

McAleece, N., P. J. D. Lambshead, G. L. J. Paterson \& J. G. Gage. 
1997. Biodiversity professional. Beta-Version. London, The Natural History Museum and the Scottish Association for Marine Sciences.

Miranda, L. E., M. P. Driscoll \& M. S. Allen. 2000. Transient physicochemical microhabitats facilitate fish survival in inhospitable aquatic plant stands. Freshwater Biology, 44(4): 617-628.

Murkin, H. R., R. M. Kaminski \& R. D. Titman. 1982. Responses by dabbling ducks and aquatic invertebrates to an experimentally manipulated cattail marsh. Canadian Journal of Zoology, 60(10): 2324-2332.

Newman, S., J. Schuette, J. B. Grace, K. Rutchey, T. Fontaine, K. R. Reddy \& M. Pietrucha. 1998. Factors influencing cattail abundance in the northern Everglades. Aquatic Botany, 60: 265280.

Nilratnisakorn, S., P. Thiravetyan \& W. Nakbanpote. 2007. Synthetic reactive dye wastewater treatment by narrow-leaved cattails (Typha angustifolia Linn.): Effects of dye, salinity and metals. Science of the Total Environment, 384(1-3): 67-76.

Novakowski, G. C., N. S. Hahn \& R. Fugi. 2007. Alimentação de peixes piscívoros antes e após a formação do reservatório de Salto Caxias, Paraná, Brasil. Biota Neotropica, 7(2): 149-154.

Patton, V. D. \& W. E. Starnes. 1970. Aquatic weeds and quarter pollution. Hyacinth Control Journal, 8(2): 48-49.

Pinto, T. L. F. \& V. S. Uieda. 2007. Aquatic insects selected as food for fishes of a tropical stream: Are there spatial and seasonal differences in their selectivity? Acta Limnologica Brasiliensia, 19(1): 67-78.

Prejs, A. \& K. Prejs. 1987. Feeding of tropical freshwater fishes: seasonality in resource availability and resource use. Oecologia, 71: 397-404.

Pusey, B. J. \& A. H. Arthington. 2003. Importance of the riparian zone to the conservation and management of freshwater fish: a review. Marine and Freshwater Research, 54: 1-16.

Silva, J. R. V. \& D. Martins. 2004. Controle químico de Typha subulata em dois estádios de desenvolvimento. Planta Daninha, 22(3): 437-443.

Ter Braak, C. J. F. \& P. Smilauer. 2002. CANOCO Reference manual and CanoDraw for Windows user's guide: Software for Canonical Community Ordination (version 4.5). Ithaca, Microcomputer Power, 500p.

Uieda, V. S. \& R. L. Motta. 2007. Trophic organization and food web structure of southeastern Brazilian streams: a review. Acta Limnologica Brasiliensia, 19(1): 15-30.

Accepted April 2009

Published June 17, 2009 